\title{
STUDY OF FACTORS AFFECTING ON THE DEVELOPMENT OF THE PHARMACEUTICAL SECTOR ENTERPRISES
}

\author{
(C) K. Golubtsova, R. Sahaidak-Nikitiuk, N. Demchenko
}

\begin{abstract}
Мета. Метою статті є дослідження факторів впливу на розвиток підприємств фармацевтичного сектору.

Матеріали та методи. До методів, які застосовувалися в дослідженні, належать методи аналізу та синтезу, математичної статистики та економіко-математичні методи. Для аналізу використовувалися дані, представлені в статистичному щорічнику Украӥни.

Результати. Досліджено сучасний стан та тендениії розвитку підприємств фармацевтичного сектору. Динаміка змін індексів споживчих ичін на фармацевтичну продукцію та обсягів ї̈ реалізаціїпротягом 2011 - 2018 рр. свідчить про їх перевищення роста иін над ростом обсягів реалізачії. Аналіз фармачевтичного ринку України висвітлив збільшення на 11 \% реалізачії обсягів фармацевтичної продукиї в доларах США. До негативних факторів розвитку фармацевтичного сектору України можна віднести зниження купівельної спроможності громадян. Порівняння частки іноземних та вітчизняних виробників на внутрішньому фармацевтичному ринку свідчить про більщу доступність українських ліків для користувача. Аналіз світового досвіду висвітлив, щяо в Україні найнижчі показники по витратах населення на придбання лікарських засобів; у той час як в Польщі, Угорщині, Болгарї цей показник у 4 рази вищий. За кількістю аптек - в Украӥні найвищі показники в абсолютному значенні. Застосовані методи математичної статистики, які дозволили виявити суцільності нефункиіональних зв 'язків між випадковими величинами, щзо дозволяє встановити наявність зв'язку між чистим результатом (прибутком) та величиною запасів фармачевтичних підприємств Харківського регіону.
\end{abstract}

Висновки. Проведене дослідження сучасного стану та тендениій розвитку підприємств фармацевтичного сектору дозволило дійти висновку, щзо прибутковість підприємств залежить від рівня організації логістичного управління (управління запасами), яке дозволить їм позбавитися зайвих витрат та вийти на новий рівень виробництва сучасних лікарських засобів

Ключові слова: фармацевтичне підприємство, фармаџевтичний сектор, управління, тенденції розвитку, запаси, лікарські засоби

\section{Introduction}

Today, the pharmaceutical industry occupies an important place in the economy of Ukraine.A positive trend is the gradual growth of the domestic producer's share in the domestic market.

The share of medicines (drugs) manufactured at pharmaceutical companies in Ukraine is approaching $45 \%$. The formation of the domestic pharmaceutical market necessitates conducting research on the current state and trends of pharmaceutical companies' development.

\section{Analysis of recent research and publications}

Problems of management of the enterprises of the pharmaceutical sector of Ukraine were considered in the work of many scientists: management standards [1, 2], the competitiveness of producers [3, 4], assortment policy [5, 6], social orientation of the industry [7], quality risk management [8], state and regional management [9], the influence of macro-focus on the activities of pharmaceutical organizations [10], logistics management [11], public administration [12], innovation policy[13, 14] etc.

\begin{abstract}
3. Selection of previously unsettled parts of the general problem

But despite a lot of attention from academics, there are a number of questions regarding the management of pharmaceutical companies that require a thorough analysis of the current state of enterprises and the prospects for their development.
\end{abstract} article

4. Formulation of goals (objectives) of the

The article is to study the current state and trends of the pharmaceutical sector enterprises.

\section{Materials and methods of research}

The research used methods of analysis and synthesis, mathematical statistics and economic and mathematical methods.

\section{Results and discussion}

In the conditions of the crisis of 2014-2015, the growth rate of the consumer price index for pharmaceutical products substantially outweighed the growth rates of the pharmaceutical product sold; in recent years, this situation has been slowly but corrected (Fig. 1). 


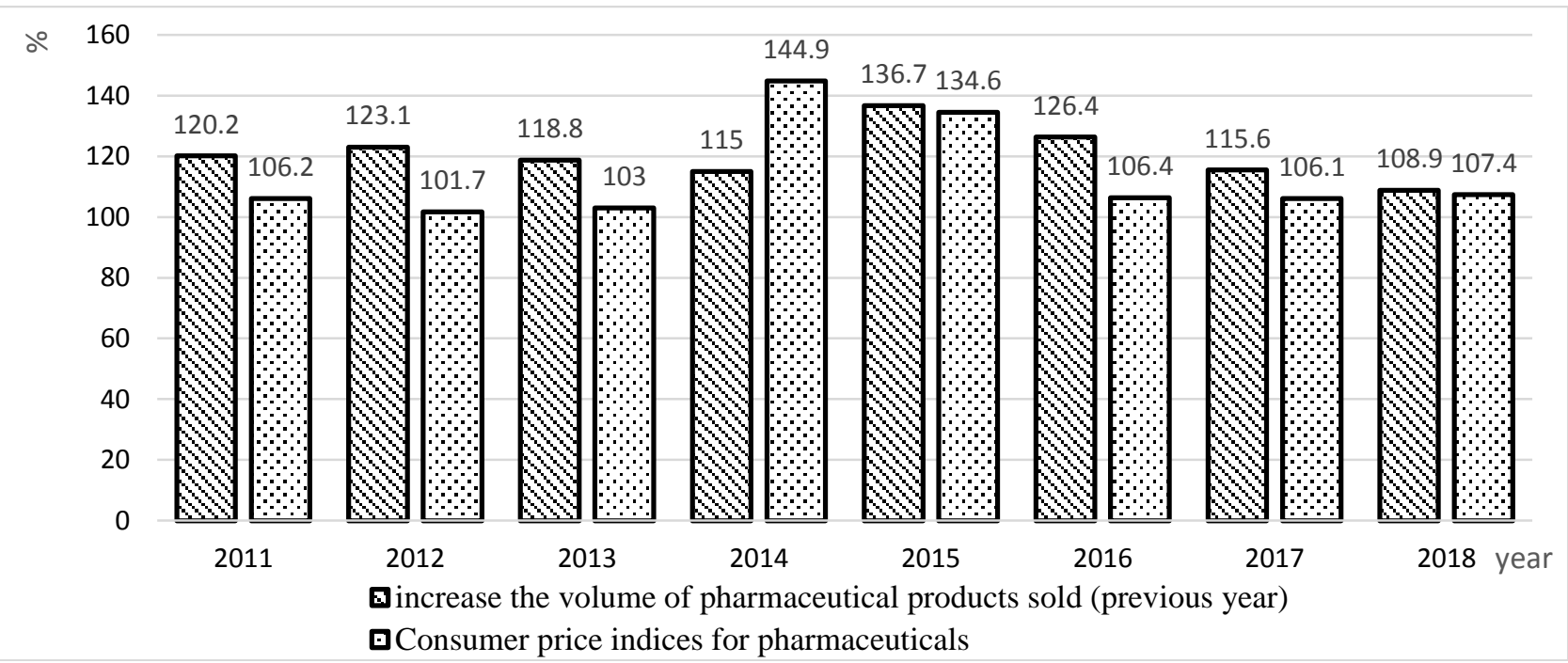

Fig. 1. Dynamics of changes in the growth rates of sales of pharmaceuticals sold (as a percentage of the previous year) and changes in consumer price indices for pharmaceutical products of Ukraine during 2011-2018. (calculated by the authors for [15])

Such tendencies are explained by the restoration of macroeconomic indicators. After all, after 2015 (the decline in the gross domestic product (GDP) was $12 \%$ ), it was observed its gradual increase by $2-3 \%$ annually.

The analysis volumes of sales of pharmaceutical productsin Ukraine shows that in 2017, for the first time since 2013, an increase of $11 \%$ in the volume of pharmaceutical products in US dollars was observed [16].

Correlation analysis of the growth rate of the volume of sales of pharmaceutical products (as a percentage of the previous year) with the tendencies of changes in consumer price indices on it testifies to a moderate relationship between these values (the calculated by the authors value of the coefficient of pair correlation is equal to $\mathrm{R}=0.63$ ).
The maintenance of the inflation rate provides the basis for forecasting a proportional increase in the volume of manufactured pharmaceutical products both in monetary terms and in natural equivalents.

The approximation of the volumes of pharmaceutical products produced by the polynomial trend line $(n=3)$ with the forecast for 2021 (Fig. 2) implies a reduction in the rate of growth due to inflation, a slow recovery of the country's macroeconomic indicators, a decrease in the incomes of the population, and a change in the structure of household expenditures, the political and economic situation in the country, increased competition from foreign producers and other factors and the output to pre-crisis levels.

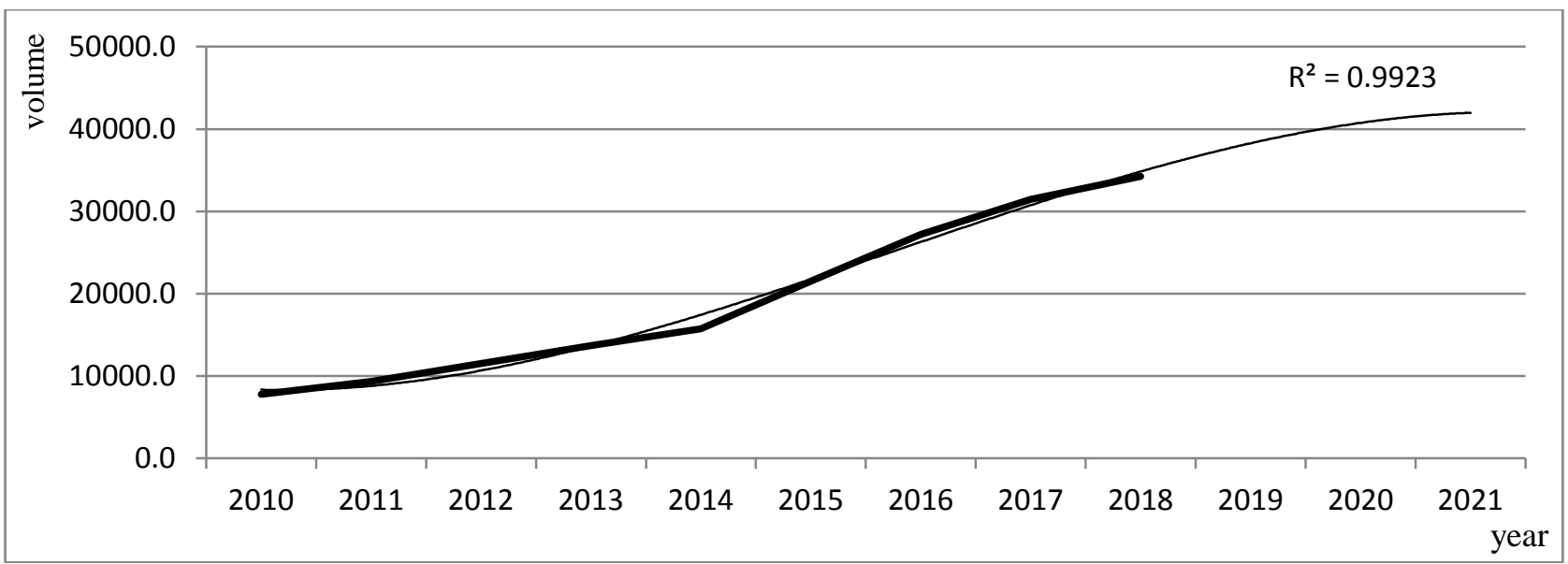

Fig. 2. Approximation of volumes of manufactured pharmaceutical products of Ukraine by polynomial trend line $(\mathrm{n}=3)$ with forecasting till 2021

In 2017, both retail and hospital sales volumes of drugs were increased, but the pace of their growth was not even.Thus, retail sales increased by $20 \%$ in cash equivalent and $7 \%$ in real terms, hospitalized by $10 \%$ and $15 \%$ respectively.

The negative factors of the pharmaceutical industry's development in Ukraine include the reduction of purchasing power of citizens. The analysis of the structure of total household expenditures shows an increase in the share of food expenditure and payment for housing and communal services to $8085 \%$. Analysis of the Ukrainian market in terms of price segments demonstrates the significant advantage of low price segment (about $59 \%$ ) above the average (26\%) and high $(15 \%)$ that is inherent in countries with weak economies. 
Comparison of the share of foreign and domestic producers in the domestic pharmaceutical market shows that the Ukrainian drugs are more accessible to the user because in foreign currency the share of foreign and domestic producers in terms of sales amounts to $63 \%$ and $37 \%$, while in kind $-27 \%$ and $73 \%$, respectively.

The low level of drug consumption in Ukraine gives experts the opportunity to argue that there is potential for the development of the pharmaceutical sector. The most influential factor is the expiration of patents on known drugs, which leads to an increase in the production of generics - authorized copies of original drugs, both in the world and in Ukraine.The price of generics is significantly cheaper than the original drugs, which gives their manufacturers an advantage in the market.So, Ukrainian drugs are cheaper than imported analogues by $4-16$ times.

In Ukraine, innovative drugs are not enough. In money terms, their share is $9 \%$, that is, $91 \%$ of all drugs sold in Ukraine, generics, and, unfortunately, most of their foreign production.
Scientific research in the pharmaceutical sector is not enough, as evidenced by the availability of their own patents for production, but their number is not sufficient in comparison with developed countries of the world.Among the leaders are PrAT FF "Darnitsa" (60 patents, 25 of them active), PAT "Farmak" (62 and 20, respectively), PJSC "Borshchagovsky KFZ" (29 and 19), PJSC "Lekhim" (8 and 5), LLC FZ "Biopharma" (4 and 2).

The transition to the production of generics for most domestic enterprises is also an overwhelming problem, because the verification of the generic bioequivalence to the original drug costs from 2 to 4 million UAH. Therefore, for the development of the pharmaceutical sector of the health sector, there is definitely a need for investment. The negative trend towards a decrease in the capital investment index in the production of basic pharmaceuticals and pharmaceuticals, observed since the onset of the economic crisis, began to be rectified only in 2017 (Fig. 3) and the level of capital investment outweighed the previous figures by $12 \%$.

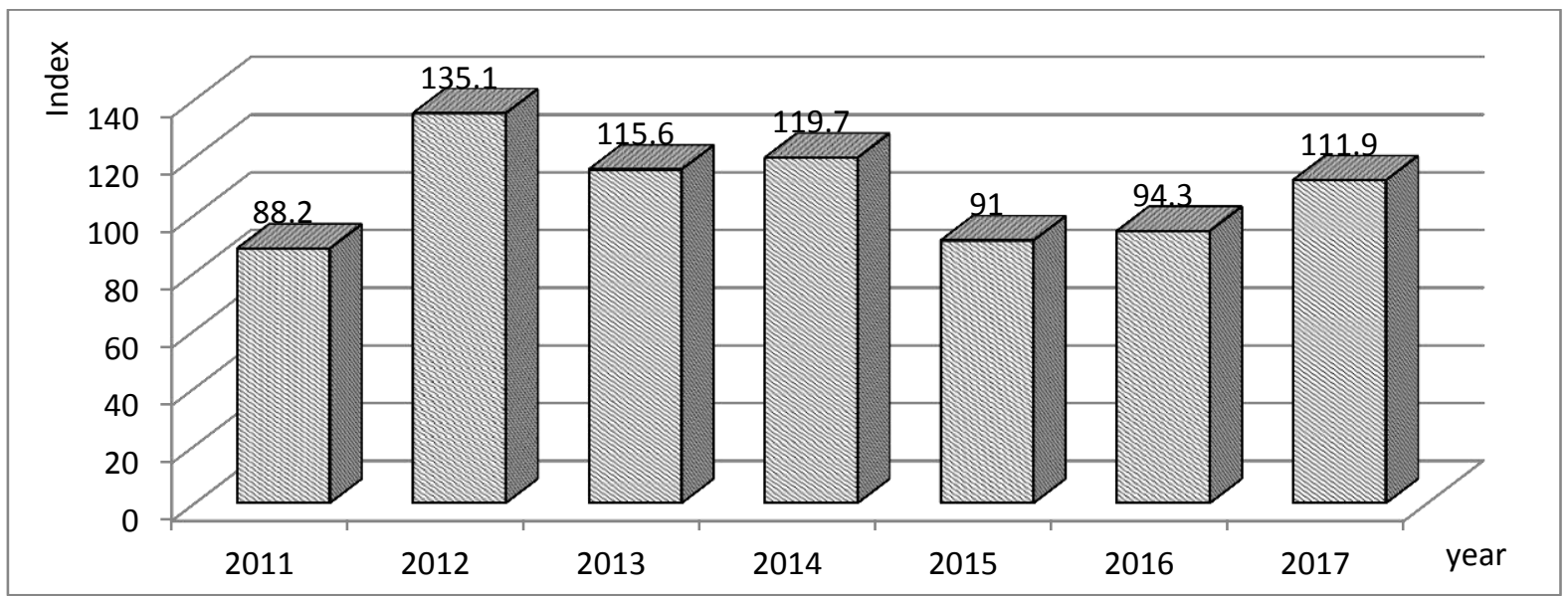

Fig. 3. Dynamics of change of capital investment index in the production of basic pharmaceutical products and pharmaceuticals of Ukraine in the period of 2011-2017 gg. (calculated for [15])

The problem of the pharmaceutical market of Ukraine is the fact that only $10-11 \%$ of it belongs to the public procurement segment, therefore almost $90 \%$ is sold in retail through a pharmacy network. Statistical data on the sales volume of pharmaceuticals through pharmacies, demographic indicators and calculated performance indicators of the pharmacy market of the nearest European neighbors of Ukraine (Table 1).

Table 1

The effectiveness of the European pharmacy 2017

\begin{tabular}{|l|c|c|c|c|c|c|}
\hline Country & $\begin{array}{c}\text { Market } \\
\text { volume, } \\
\text { billion euro }\end{array}$ & $\begin{array}{c}\text { Population, } \\
\text { million } \\
\text { people }\end{array}$ & $\begin{array}{c}\text { Turnover } \\
\text { per person }\end{array}$ & $\begin{array}{c}\text { The number of } \\
\text { pharmacies }\end{array}$ & $\begin{array}{c}\text { Number of people } \\
\text { served by 1 phar- } \\
\text { macy }\end{array}$ & $\begin{array}{c}\text { Pharmacy } \\
\text { turnover } \\
\text { per year }\end{array}$ \\
\hline Poland & 7.8 & 38.5 & 202.6 & 14716 & 2616 & 530035.3 \\
\hline Romania & 2.6 & 19.9 & 130.7 & 9429 & 2111 & 275745.0 \\
\hline Ukraine & 2 & 42.3 & 47.3 & 22474 & 1882 & 88991.7 \\
\hline Hungary & 1.9 & 9.8 & 193.9 & 3220 & 3043 & 590062.1 \\
\hline Czech Republic & 1.7 & 10.6 & 160.4 & 2804 & 3780 & 606276.7 \\
\hline Bulgaria & 1.5 & 7.1 & 211.3 & 4207 & 1688 & 356548.6 \\
\hline Belarus & 0.7 & 9.5 & 73.7 & 3196 & 2972 & 219023.8 \\
\hline
\end{tabular}

The analysis of the results shows that in Ukraine the lowest indicators of population spending on the purchase of medicines (less than 50 euros per year); while in Poland, Hungary, Bulgaria this figure is 4 times higher. By the number of pharmacies - in Ukraine, the highest figures in absolute terms, therefore, the population 
served by one pharmacy - from the worst (Ukraine outstripped only Bulgaria: 1882 against 1688).This affects the effectiveness of each drug (88991.7 €/year vs. 606276.7 €/year in the Czech Republic 590,062.1 €/year in Hungary or $530035.3 € /$ year in Poland, that is 6-7 times less).If we take a sample of Poland - similar to Ukraine by population, it notes that in Ukraine 1.5 times the pharmacies that are definitely covered on their performance.

Kharkiv pharmaceutical complex consists of 11 enterprises, among which the main producers are LLC Pharmaceutical Company Zdorovye, OJSC LekhimKharkov, AO Stoma, HGFP Zdorovye Naroda, OJSC HFZ Krasnaya Zvezda, Experimental Plant GNTsLS, "State Enterprise Chemical Reagents Plant", ZAO "Biolek". Two of them are included in the TOP 10 pharmacological enterprises of Ukraine in terms of pharmacy sales of LLC "FC Zdorovya" confidently ranked 5-th in the rating in recent years, and LekhimKharkov OJSC improved its position by 2 points and took 7-th place.LLC "FC Zdorovya" occupies the leading positions on state purchases in Ukraine, and has occupied 2nd place in 2017, has improved its rating by 3 positions in comparison with the previous year, conceding only to the Irish company AbbVie. The share of the "Zdorovya" group of companies reaches $5.4 \%$ of the total market segment of public procurement of pharmaceuticals.

For research and comparative analysis, 4 pharmaceutical enterprises of the Kharkiv region were selected: Pharmaceutical Company Zdorovya LLC, PJSC "Lekhim-Kharkiv", JSC "Stoma", PJSC "KhFZ" Chervona Zirka".The results of calculating the share of each type of stocks of pharmaceutical enterprises in the Kharkiv region $[17,18]$ are summarized in Table 2.

Table 2

Structure of stocks in the balance of pharmaceutical enterprises of the Kharkiv region

\begin{tabular}{|c|c|c|c|c|}
\hline & 2014 & 2015 & 2016 & 2017 \\
\hline \multicolumn{5}{|c|}{ LLC "Pharmaceutical company "Zdorovya" } \\
\hline inventories & 49.94 & 44.44 & 48.39 & 48.04 \\
\hline unfinished production & 14.44 & 11.62 & 12.57 & 12.38 \\
\hline finished goods & 33.12 & 41.03 & 34.66 & 36.94 \\
\hline products & 2.49 & 2.92 & 4.37 & 2.65 \\
\hline \multicolumn{5}{|c|}{ PJSC "Lekhim-Kharkiv" } \\
\hline inventories & 67.29 & 66.36 & 67.49 & 72.31 \\
\hline unfinished production & 8.39 & 8.23 & 7.50 & 12.58 \\
\hline finished goods & 24.31 & 25.41 & 25.01 & 15.10 \\
\hline products & 0.00 & 0.00 & 0.00 & 0.00 \\
\hline \multicolumn{5}{|c|}{ JSC "Stoma" } \\
\hline inventories & 51.78 & 51.13 & 57.84 & 66.11 \\
\hline unfinished production & 7.79 & 5.03 & 8.25 & 8.00 \\
\hline finished goods & 40.44 & 43.83 & 33.91 & 25.89 \\
\hline products & 0.00 & 0.00 & 0.00 & 0.00 \\
\hline \multicolumn{5}{|c|}{ "KhFZ"Chervona Zirka" } \\
\hline inventories & 55.27 & 57.71 & 63.08 & 53.02 \\
\hline unfinished production & 6.90 & 3.71 & 5.60 & 3.66 \\
\hline finished goods & 37.66 & 38.56 & 31.32 & 43.32 \\
\hline products & 0.18 & 0.02 & 0.00 & 0.00 \\
\hline
\end{tabular}

The share of production stocks of the Pharmaceutical Company Zdorovya LLC is almost unchanged and accounts for half of all stocks, and a third falls on finished products. The share of unfinished production and goods varies from 12.5 to $14.5 \%$ and from 2.5 to $4.5 \%$, respectively. In PJSC "LekhimKharkiv", 2/3 of the stock falls on production, and their share is increasing, 1/4 - on finished products, and its share decreases. The share of work in progress ranges from $7.5 \%$ to $12.5 \%$. There is almost no stock in the goods. For JSC "Stoma" we note an increase in the share of production stocks from $52 \%$ to $66 \%$, and the reduction of finished products from $40 \%$ to $26 \%$. The share of work in progress ranges from $5 \%$ to $8 \%$, inventories are almost non-existent. According to the share of production and finished products, the stock structure of PJSC "KhFZ" Chervona Zirka "is similar to the corresponding structure of"Pharmaceutical company "Zdorovya" LLC. The share of incomplete production varies within the limits of $47 \%$, the stock in the goods is insignificant.

A correlation analysis was chosen for the study $[19,20]$. It allows to set the level of dependence of one random variable on the other. The value of the relationship between random variables by the magnitude of the correlation coefficient is set according to the rule: $0 \leq R_{x y}<0.2$ is very weak; $0.2 \leq R_{x y}<0.3$ is weak; $0,3 \leq R_{x y}<0,5$ moderate; $0.5 \leq R_{x y}<0.7$ average; $0,7 \leq R_{x y}<0,8$ strong; $0,8 \leq R_{x y} \leq 1,0$ is very strong.

Calculated values of the coefficient of pair correlation between the values of net profit and stocks of enterprises in the Kharkiv region are presented in Table 3. 
Value of the pair correlation coefficients between the values of net profit and the stocks of the Kharkiv region's pharmaceutical enterprises

\begin{tabular}{|l|c|l|}
\hline \multicolumn{1}{|c|}{ Enterprise } & $R_{x y}$ & Interpreting the result \\
\hline LLC "Pharmaceutical company Zdorovya" & 0.75 & Strong, straight \\
\hline PJSC "Lekhim-Kharkiv" & 0.90 & Very strong, straight \\
\hline JSC "Stoma" & -0.96 & Very strong, inverse \\
\hline "KhFZ" Chervona Zirka" & 0.98 & Very strong, straight \\
\hline
\end{tabular}

Almost all selected pharmaceutical companies have a strong and very strong link between stock availability and profitability.

\section{Conclusions}

1. The trends, typical for the modern pharmaceutical market, which testify to the gradual growth of volumes of manufactured products and the correction of the situation caused by the crisis that has developed in the country, are analyzed.

2. The conducted studies revealed an increase of $11 \%$ in the volume of pharmaceutical products in US dollars, while the approximation of volumes of manufactured pharmaceutical products in Ukraine has a polynomial trend line and implies a reduction in the rates of its growth due to inflation and their output to pre-crisis levels. The negative trend is also the index of capital investments in the production of basic pharmaceuticals and pharmaceuticals of Ukraine in 2011-2017.

3 . Analysis of the stocks of pharmaceutical enterprises in the Kharkiv region shows that almost all companies account for a third of the stock of finished products, the share of work in progress ranges from $12.5 \%$.

4. On the basis of correlation analysis, for almost all selected pharmaceutical companies, a strong connection was found between stock availability and profitability of the enterprise.

5. The study of the current state and trends in pharmaceutical companies' development has made it possible to conclude that the profitability of enterprises in the pharmaceutical sector depends on the level of organization of logistics management (inventory management), which will allow them to get rid of excess costs and reach a new level of production of high-quality pharmaceutical products.

The prospect of further research should be the scientific substantiation of the use of marketing logistics tools in the context of increasing the competitiveness of domestic pharmaceutical products and pharmaceutical industry.

\section{References}

1. Hromovyk B. P. Standarty farmatsevtychnoho upravlinnia // Farmatsevtychnyi zhurnal. 2004. Issue 3. P. 18-28.

2. Hromovyk B. P., Tereshchuk S. I., Chukhrai I. L. Orhanizatsiia ta ekonomika farmatsii / ed. by Hromovyk B. P., Tereshchuk S. I. Vinnytsia: NOVA KNYHA, 2009. 816 p.

3. Gholamhossein M., Hosein S. The Importance of Competitiveness in New Internationalized and Competitive Environment of Pharmaceutical Industry // Iranian journal of pharmaceutical research. 2014. Issue 13 (2). P. 351-352.

4. Frolova H. I., Frolova V. Yu. Konkurentospromozhnist pidpryiemstv farmatsevtychnoi haluzi Ukrainy // Visnik Berdianskoho universytetu menedzhmentu i biznesu. 2012. Issue 1 (17). P. 146-152.

5. Kotvitska A. A., Kostiuk V. H. Doslidzhennia suchasnykh pidkhodiv do formuvannia asortymentnoi polityky vitchyznianykh farmatsevtychnykh pidpryiemstv // Sotsialna farmatsiia v okhoroni zdorovia. 2016. Vol. 2, Issue 2. P. $37-43$.

6. Kotvitska A. A. Metodolohiia sotsialnoi spravedlyvosti farmatsevtychnoho zabezpechennia naselennia // Farmatsevtychnyi zhurnal. 2008. Issue 2. P. 8-12.

7. Kutsenko V. Zdorovia natsii yak stratehichnyi resurs derzhavy // Visnyk Natsionalnoi Akademii Nauk Ukrainy. 2009. Issue 6. P. 44-51.

8. Lebedynets V. O., Kovalenko S. M. Otsiniuvannia, analizuvannia ta upravlinnia ryzykamy dlia yakosti na farmatsevtychnomu pidpryiemstvi // Upravlinnia, ekonomika ta zabezpechennia yakosti v farmatsii. 2011. Issue 6 (20). P. 10-15.

9. Nemchenko A. S., Khomenko V. M., Yarmola I. K. Ekspertna otsinka problem derzhavnoho ta rehionalnoho upravlinnia farmatsevtychnoiu haluzziu // Farmatsevtychnyi zhurnal. 2008. Issue 1. P. 3-9.

10. Pestun I. V., Mnushko Z. M. Stan ta perspektyvy makrootochennia na diialnist farmatsevtychnykh orhanizatsii v Ukraini // Upravlinnia, ekonomika ta zabezpechennia yakosti v farmatsii. 2008. Vol. 1, Issue 1. P. 8-14.

11. Lohistychnyi menedzhment farmatsevtychnoho pidpryiemstva: monograph / Posylkina O. V., Sahaidak-Nikitiuk R. V., Zahorii H. V., Horbunova O. Yu., Yurchenko A. P. Kharkiv: NFaU, 2011. 772 p.

12. Derzhavne upravlinnia okhoronoiu zdorovia v Ukraini: henezys i perspektyvy rozvytku / ed. by Bilynska M. M., Radysh Ya. F. Kyiv: NADU, 2013. 424 p.

13. The Pharmaceutical Industry in Figures. The European Federation of Pharmaceutical Industries and Associations. URL: https://efpia.eu/publications/downloads/efpia/2018-the-pharmaceutical-industry-in-figures/

14. Singh A., Henske P. Has the Pharmaceutical Blockbuster Model Gone Bust? A New Bain \& Company Reveals New Drug Commercialization Costs Have Now Reached \$1.7 Billion While ROI Has Plummeted to Just $5 \%$. 2003. URL: https://www.businesswire.com/news/home/20031208005181/en/Pharmaceutical-Blockbuster-Model-Bust-New-Bain-Company

15. Statystychnyi shchorichnyk Ukrainy. URL: http://www.ukrstat.gov.ua/druk/publicat/kat_u/publ1_u.htm

16. Problemy i perspektyvy diialnosti farmatsevtychnykh kompanii v Ukrainu. URL: https://procapital.ua/press_center/procapprog/view/12/

17. Butnyk O. M. Ekonomiko-matematychne modeliuvannia perekhidnykh protsesiv u sotsialno-ekonomichnykh systemakh: monograph. Kharkiv: Vyd.Dim «Inzhek»; SPD Liburkina L. M., 2004. 304 p.

18. Nakonechnyi S. I., Savina S. S. Matematychne prohramuvannia: textbook. Kyiv: KNEU, 2004. 432 p. 